\title{
PERANAN BIDANG PERSONALIA TERHADAP PEMBINAAN PEGAWAI DI DINAS PERHUBUNGAN KOTA BANDAR LAMPUNG
}

\author{
Oleh: \\ Soewito ${ }^{1}$ \\ Kodri $^{2}$ \\ Program Studi Ilmu Administrasi Bisnis, Universitas Bandar Lampung \\ e-Mail: soewito@gmail.com
}

\begin{abstract}
ABSTRAK
Dalam rangka mewujudkan pembangunan transportasi yang efisien, efektif dan terpadu tersebut maka sistem transportasi perlu ditata sedemikian rupa, dengan tetap mengacu kepada rencana tata ruang wilayah. Merujuk pada hal tersebut di atas maka diperlukan sumber daya manusia yang mempunyai kualitas yang berimbang dengan kebutuhan dan tuntunan permasalahan yang dihadapi.

Masalah pokok dalam penelitian ini adalah apakah bidang personalia mempunyai peranan yang positif dalam pembinaan pegawai di Dinas Perhubungan Kota Bandar Lampung. Hipotesis dalam penelitian ini adalah bidang personalia mempunyai peranan yang positif dalam pembinaan pegawai di Dinas Perhubungan Kota Bandar Lampung.

Populasi dalam penelitian ini adalah pegawai Dinas Perhubungan Kota Bandar Lampung yang berjumlah 50 orang. Sampel dalam penelitian ini yaitu $50 \% \times 50=25$ orang pegawai/staf Dinas Perhubungan Kota Bandar Lampung.

Setelah dilakukan penelitian, didapatkan kesimpulan bahwa bidang personalia berperan dalam pembinaan pegawai di Dinas Perhubungan Kota Bandar Lampung, hal ini dikarenakan perencanaan dan pembinaan karir serta keahlian pegawai yang baik. Berdasarkan hasil perhitungan, maka di dapat untuk rhitung adalah 0,518. Apabila dikonsultasikan dengan rtabel untuk taraf signifikan 5\% adalah 0,396. Ternyata rhitung lebih besar dari pada rtabel atau rhitung $(0,518)>$ rtabel $(0,396)$ pada taraf signifikan $5 \%$, dengan demikian bidang personalia mempunyai peranan yang positif terhadap Pembinaan Pegawai di Dinas Perhubungan Kota Bandar Lampung.
\end{abstract}

Kata kunci: personalia, pembinaan, dinas perhubungan Bandar Lampung

\section{PENDAHULUAN}

\subsection{Latar Belakang Masalah}

Dalam penjelasan umum UndangUndang Nomor 43 Tahun 1999, antara lain dinyatakan bahwa kelancaran penyelenggaraan tugas pemerintahan dan pelaksanaan pembangunan nasional sangat tergantung pada kemampuan aparatur Negara, khususnya Pegawai Negeri Sipil. 
Karena itu, dalam rangka mencapai tujuan pembangunan nasional, untuk mewujudkan masyarakat yang taat hukum, beperadaban modern, demokzsatis, makmur, adil dan bermoral tinggi diperlukan Pegawai Negeri Sipil yang merupakan unsure aparatur Negara yang bertugas sebagai abdi masyarakat, yang menyelenggarakan pelayanan secara adil dan merata kepada masyarakat dengan dilandasi kesetiaan dan ketaatan kepada Pancasila dan Undang-Undang Dasar 1945.

Untuk menjamin penyelenggaraan tugas pemerintahan dan pembangunan secara berdaya guna dan berhasil guna, diperlukan sistem pembinaan Pegawai Negeri Sipil yang mampu memberikan keseimbangan terjaminnya hak dan kewajiban Pegawai Negeri Sipil, dengan misi tiap satuan organisasi pemerintah untuk memotivasi kinerja Pegawai Negeri Sipil perlu disusun pola karier yang memungkinkan potensi Pegawai Negeri Sipil dikembangkan seoptimal mungkin dalam rangka misi organisasi pemerintah yang akhirnya pencapaian tujuan nasional dapat dilaksanakan secara lebih efektif.

Peran transportasi r dalam
mendukung pertumbuhan $\begin{array}{r}\text { ekonomi } \\ \text { meningkat sejalan dengan pertumbuhan } \\ \text { produk Regional Domestik Bruto Lampung }\end{array}$
dan perubahan struktur ekonomi, dimana
sector pertanian tumbuh lebih cepat dari
sector industri. Peningkatan pertumbuhan
dan perubahan/pergeseran nilai ini
memerlukan peningkatan jasa
perhubungan, khususnya transportasi dan
telekomunikasi. Disisi lain. Transportasi
berperan juga dalam penyebaran penduduk
keseluruh wilayah, sehingga transportasi
tidak hanya berperan dalam menumbuh
kembangkan perekonomian nasional tetapi
juga mendukung pembangunan dibidang-
bidang lainnya.

Pembangunan sistem transportasi yang efisien, efektif dan terpadu sangat diperlukan dalam upaya menekan biaya transportasi, sehingga produk-produk industri dan pertanian menjadi lebih kompetitif di pasar internasional yang pada gilirannya mendatangkan devisa khususnya bagi daerah dan Negara pada umumnya. Di samping itu keterpaduan sistem transportasi antar moda diperlukan, dimana jaringan transportasi merupakan satu kesatuan jaringan prasarana dan jaringan pelayanan transportasi darat, laut dan udara.

Dalam rangka mewujudkan pembangunan transportasi yang efisien, efektif dan terpadu tersebut maka sistem transportasi perlu ditata sedemikian rupa, dengan tetap mengacu kepada rencana tata ruang wilayah.

Merujuk pada hal tersebut di atas maka diperlukan sumber daya manusia yang mempunyai kualitas yang berimbang dengan kebutuhan dan tuntunan permasalahan yang dihadapi.

\subsection{Tujuan Penelitian}

Adapun tujuan yang ingin dicapai dalam penelitian ini adalah :

a. Untuk mengetahui hal apa saja yang telah dilakukan bidang personaliaDinas Perhubungan Kota Bandar Lampung dalam melakukan pembinaan terhadap pegawainya.

b. Untuk mengetahui bagaimana bidang personalia Dinas Perhubungan Kota Bandar Lampung menjalankan tugas dan fungsinya.

c. Diharapkan dapat memberikan sumbangan pemikiran bagi Dinas Perhubungan Kota Bandar Lampung. 


\subsection{Kerangka Pemikiran}

Menurut Filippo (1988:5), bidang personalia adalah bidang yang menangani perencanaan pengorganisasian, pengarahan dan pengendalian atas pengadaan tenaga kerja, pengembangan, kompensasi, integrasi, pemeliharaan, dan pemutusan hubungan kerja dengan sumber daya manusia untuk mencapai sasaran perorangan, organisasi, dan masyarakat.

Menurut Handoko (2005:9), manajer personalia adalah seorang manajer dan sebagai manajer harus melaksanakan fungsi-fungsi dasar manajemen tanpa memperdulikan apapun hakekat fungsi operasional.

Dalam bentuk kerangka, definisi tersebut akan tampak sebagai berikut:

1. Fungsi-fungsi manajemen
a. Perencanaan
b. Pengorganisasian
c. Pengarahan
d. Pengendalian

2. Fungsi-fungsi operasional
a. Pengadaan tenaga kerja
b. Pengembangan
c. Kompensasi
d. Integrasi
e. Pemeliharaan
f. Pemutusan hubungan kerja

Menurut Musanef (1996:14)
adapun tujuan pembinaan pegawai
diarahkan pada usaha-usaha untuk:

1. Memiliki jumlah pegawai yang cukup memenuhi persyaratan, sehingga dapat digunakan secara efisien untuk membantu pimpinan dalam melaksanakan tugas.

2. Membantu pegawai untuk meningkatkan profesionalisme dan kemampuan.

3. Menciptakan suasana dalam hubungan kerja yang dapat menimbulkan rangsangan positif kepada para pegawai agar dapat memberikan prestasi.

Dan dalam prakteknya, penerapan pembinaan pegawai bukanlah hal yang mudah karena ada kelemahan yang akan timbul di dalamnya, diantaranya:

1. Seorang manajer akan menghadapi para pegawainya yang berasal dari berbagai kalangan yang tentunya mempunyai latar belakang pendidikan yang berbeda antara pegawai yang satu dengan yang lain, sifat dan karakteristik serta suku yang berbeda pula.

2. Dan meskipun telat memperoleh karyawan, mengembangkan mereka serta memberikan kompensasi yang layak, tetapi perusahaan tetap akan menghadapi masalah yang sulit, yakni dengan proses integrasi. Integrasi menyangkut penyesuaian keinginan karyawan dengan tujuan perusahaan.

Gambar 1. Kerangka pikir

\begin{tabular}{|l|}
\hline \multicolumn{1}{|c|}{ Variabel $\mathrm{x}$} \\
Peranan bidang personalia \\
\hline - \\
- Perencanaan \\
- \\
Pengorganisasian \\
Pengendalian
\end{tabular}

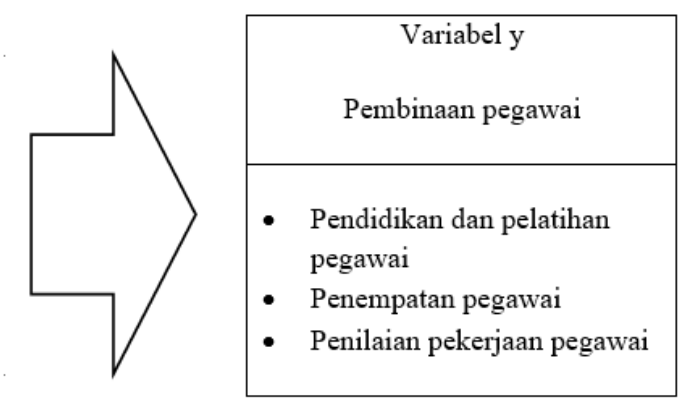




\subsection{Hipotesis}

Trelease (dalam Moh. Nasir 1999 : 182), mendefinisikan hipotesa sebagai keterangan sementara dari suatu fakta yang dapat diamati. Sedangkan Good and Scates (dalam Moh. Nasir 1999 : 60) menyatakan bahwa hipotesa adalah sebuah taksiran atau referensi yang dirumuskan serta diterima untuk sementara yang dapat menerangkan fakta-fakta yang diamati ataupun kondisikondisi yang diamati. Dan digunakan sebagai petunjuk untuk langkah penelitian selanjutnya. Berdasarkan pendapat di atas, maka hipotesis dalam penelitian ini adalah Bidang personalia mempunyai peranan yang positif dalam pembinaan pegawai di Dinas Perhubungan Kota Bandar Lampung.

\section{LANDASAN TEORI}

\subsection{Pembinaan Pegawai Tertentu}

\section{Pengertian Pembinaan Pegawai}

Dalam pelaksanaan pembinaan pegawai diarahkan pada makin terwujudnya pegawai yang mampu mengembangkan karier berdasarkan prestasi kerja, kemampuan profesional, keahlian dan keterampilan. Dengan kata lain pegawai diberikan kebebasan dalam meningkatkan kinerjanya untuk mencapai tujuan yang diharapkan dalam rangka pengembangan karir, keahlian, dan keterampilan, namun tetap diarahkan dalam prosesnya yaitu dengan melakukan pengawasan dan memberikan pembinaan yang tepat sasaran. | Menurut Pamudji (1991 : 25) pengertian pembinaan pegawai ada 2 (dua) yaitu:

a. Pembinaan diartikan sebagai pembangunan yaitu merupakan perubahan sesuatu menjadi yang baru yang memiliki nilai-nilai yang lebih tinggi. b. Pembinaan diartikan sebagai pembaharuan yaitu melakukan suatu usaha untuk membuat sesuatu menjadi lebih baik dan bermanfaat.

Berdasarkan hal tersebut maka pembinaan pegawai merupakan upaya untuk mendapatkan pegawai dan mengembangkan profesionalisme serta keterampilan sesuai tuntutan tugas organisasi sehingga dapat menghasilkan prestasi kerja yang sebaik-baiknya guna mencapai tujuan, sasaran dan program kerja yang telah ditetapkan.

Berdasarkan uraian diatas maka dapat ditarik kesimpulan bahwa yang dimaksud dengan pembinaan pegawai adalah aktivitas atau kegiatan yang dilakukan dalam rangka membina pegawai, mengembangkan profesionalisme dengan memberikan pendidikan dan latihan yang bertujuan untuk meningkatkan suatu prestasi kerja sehingga menghasilkan pegawai yang berhasil guna dan berdaya guna. Pembinaan pegawai yang dimaksud pada dasarnya meliputi:

a. Diarahkan untuk menjamin penyelenggaraan tugas-tugas pokok dan fungsi organisasi secara berdaya guna dan berhasil guna.

b. Untuk meningkatkan profesionalisme dan keterampilan serta memupuk kegairahan kerja.

c. Diarahkan pada terwujudnya pegawai yang memadai sehingga mampu menghasilkan prestasi kerja yang baik (Musanef, 1997 : 17).

Namun secara operasional pembinaan pegawai pada dasarnya mencakup jumlah, komposisi dan tata nilai serta berdaya kerja sebagai salah satu faktor yang sangat menentukan terhadap keberhasilan suatu organisasi 
baik instansi pemerintah, BUMN, BUMD maupun BUMS. Selanjutnya dalam proses pembinaan pegawai guna mengimbangi penerapan ilmu pengetahuan dan teknologi (IPTEK) serta kesempatan berperan maka:

a. Pembinaan pegawai merupakan aset utama dan mempunyai posisi kunci dalam upaya pencapaian keberhasilan suatu organisasi.

b. Dari segi jumlah, komposisi dan kualifikasi pegawai guna menyelenggarakan tugas pokok dan fungsi organisasi, maka pembinaan pegawai dirancang atas dasar peningkatan efisiensi dan produktivitas secara optimal dalam upaya pencapaian target dan sasaran organisasi.

c. Komposisi diantara kelompok keahlian/profesional maupun tingkat keterampilan pelaksanaan tugas merupakan syarat bagi terciptanya disiplin dan etos kerja, yang dirancang dengan perbandingan dimana profesionalisme dan tenaga terdidik mendapat porsi serta kesempatan yang lebih besar sepanjang memenuhi kriteria tertentu bagi suatu jabatan.

d. Sejalan dengan tingkat kebutuhan, pembinaan pegawai dilakukan secara terus menerus, dengan peningkatan masa belajar di dalam masa bakti merupakan jalan keluar yang tepat.

\section{Tujuan dan Kegunaan Pembinaan Pegawai}

Membina dan mengembangkan pegawai atau bawahan merupakan tugas para pimpinan perusahaan. Pimpinan suatu perusahaan merupakan orang yang menentukan apakah seorang pegawai itu berharga atau tidak berharga bagi organisasi tempat dimana dia bekerja. Ini ditentukan oleh sikap pemimpin itu sendiri, terhadap organisasinya dan terhadap pegawainya. Jadi dengan demikian jelaslah pula bahwa pembinaan pegawai yang bertujuan untuk mengembangkan kemampuan pegawai dalam suatu organisasi banyak ditentukan oleh pemimpin atau atasannya.

Dalam pelaksanaan pembinaan pegawai, jika pemimpin merasa berkewajiban untuk membina dan mengembangkan pegawainya, maka pada saat seseorang menjabat sebagai pemimpin, pada saat itu pula seorang pemimpin sudah harus memikirkan berbagai hal mengenai tugas-tugasnya dalam rangka membina bawahannya. Bagi seorang pemimpin, harus jelas apakah yang menjadi tujuan dari pembinaan pegawai, apakah kegunaan dari pembinaan pegawai bukan saja bagi pegawai tetapi bagi organisasi yang dipimpinnya, dan juga bagi seorang pemimpin harus jelas dan tegas pula dimana authority yang dipegangnya dalam rangka pembinaan bawahan tersebut.

Berdasarkan dari uraian tersebut diatas, maka dalam mencapai tujuan pembinaan pegawai yang efektif diharapkan akan memperoleh 3 (tiga) hal sebagai berikut :

1. Menambah pengetahuan

2. Menambah keterampilan

3. Merubah sikap

Tujuan dari pembinaan pegawai menurut pendapat Dale Yoder yang dikutip oleh Manulang (1987 :14), dapat disimpulkan bahwa pada umumnya adalah sebagai berikut:

a. Supaya pegawai dapat melakukan pekerjaan lebih efisien 
b. Supaya pengawasan lebih sedikit terhadap pegawai

c. Supaya pegawai lebih cepat berkembang

d. Menstabilisasi pegawai

Dalam melakukan pekerjaan yang merupakan tugasnya, pegawai akan lebih efisien mengerjakannya jika telah diberikan pembinaan dibandingkan dengan cara mengerjakan sebelum ia mengikuti pembinaan yang bersangkutan. Hal ini disebabkan karena dengan diberikannya pegawai pembinaan, pelatihan, dan pengembangan, maka selama proses pembinaan pegawai akan mendapat pengetahuan atau ditambah pengetahuannya bagaimana cara-cara terbaik dalam melakukan suatu pekerjaan/kegiatan, maka pegawai mengetahui dan menguasai cara-cara untuk mengerjakan suatu pekerjaan.

$\begin{array}{clr}\text { Bila } & \text { pegawai } & \text { diberikan } \\ \text { pelatihan, } & \text { pembinaan } & \text { atau }\end{array}$ dikembangkan, maka salah satu tujuannya ialah agar pemimpin dapat mengurangi pengawasan terhadap pegawai tersebut. Dengan demikian pegawai yang lebih terampil akan lebih mempunyai pengetahuan dalam mengerjakan suatu pekerjaan sehingga pimpinan tidak perlu lagi selalu mengawasinya.

Dibandingkan dengan pegawai yang telah melalu kegiatan-kegiatan yang sengaja diarahkan atau dibina, perkembangan seorang pegawai akan terasa terhambat atau terlambat. Untuk itu seorang pemimpin yang mengharapkan perkembangan bawahan yang relatif cepat haruslah mengambil langkah-langkah kearah pengembangan pegawai, yaitu dengan cara memberikan pembinaan dan latihanlatihan, sehingga tujuan dari pembinaan pegawai dalam rangka mengembangkan pegawai dengan lebih cepat akan dapat terlaksana.

Tujuan dari pembinaan pegawai menurut pendapat Musanef (2000 : 18) mencakup kegiatankegiatan sebagai berikut:

1. Diarahkan untuk menjamin penyelenggaraan tugas-tugas pembangunan secara berdaya guna dan berhasil guna baik BUMN/BUMD/BUMS.

2. Untuk meningkatkan mutu keahlian/profesionalisme dan keterampilan serta) memupuk kegairahan bekerja, ketaatan dan kepatuhan serta kesabaran disiplin pribadi.

3. Diarahkan pada terwujudnya suatu komposisi pegawai yang serasi harmonis sehingga menghasilkan prestasi kerja yang baik.

4. Ditujukan kepada terwujudnya suatu iklim kerja yang serasi menjamin terciptanya Kesejahteraan yang layak, bukan saja untuk makan tapi kebutuhan pokok lain sehingga mampu melaksanakan tugas dengan baik.

5. Diarabkan kepada penempatan pegawai secara teratur terpadu dan berimbang atas dasar kriteriakriteria yang sesuai secara individu maupun kelompok sehingga dapat memberikan manfaat bagi instansi atau organisasi yang bersangkutan.

Sedangkan kegunaan dari pembinaan pegawai menurut pendapat Manulang (1990 : 15) dapat dilihat berdasarkan dua segi, yaitu:

1. Segi pegawai/individu Berdasarkan segi pegawai /individu, maka pembinaan pegawai memberikan kegunaan dalam hal-hal sebagai berikut: 
a. Menambah pengetahuan

b. Menambah dan memperbaiki keahlian, sekaligus memperbaiki cara-cara pelaksanaan kerja yang lama

c. Merubah sikap

d. Memperbaiki atau menambah imbalan atau balas jasa yang diperoleh dan organisasi tempat kerja.

2. Segi organisasi Berdasarkan segi organisasi, maka pembinaan pegawai itu dapat memberikan kegunaan alam hal sebagai berikut :

a. Menaikkan produktivitas pegawai

b. Menurunkan biaya

c. Mengurangi turn over pegawai

d. Kemungkinan memperoleh keuntungan yang lebih besar karena direalisir ketiga faedah tersebut lebih dulu

e. Memperbaiki image kepada organisasi, sebagai suatu organisasi yang progresif, perbaikan image ini dapat menarik calon-calon pegawai yang terbaik untuk mengisi lowongan-lowongan dalam organisasi

Berdasarkan dari uraian diatas, maka penulis mengambil suatu kesimpulan bahwa betapa pentingnya peranan pembinaan pegawai bagi seseorang pegawai dalam melaksanakan suatu tugas. Adanya pembinaan pegawai, akan menjamin tersedianya tenaga-tenaga dalam perusahaan yang mempunyai keahlian dan kecakapan pikirannya secara kritis. Di samping hal tersebut melalui pembinaan yang di dalamnya terdapat kegiatan pendidikan dan latihan, maka akan mendorong mereka untuk memberikan jasanya dalam waktu yang lebih lama dan juga dapat memperbaiki cara bekerja dan moral mereka.

\subsection{Sistem Pembinaan Karier Pegawai}

System pembinaan karier pegawai harus disusun sedemikian rupa, sehingga menjamin terciptanya kondisi objektif yang dapat mendorong peningkatan prestasi pegawai. Hal tersebut dapat dimungkinkan apabila penempatan Pegawai Negeri Sipil didasarkan atas tingkat keserasian antara persyaratan jabatan dengan kinerja pegawai yang bersangkutan. System pembinaan karier pegawai pada hakikatnya adalah suatu upaya sistematik, terencana yang mencakup struktur dan proses yang menghasilkan keselarasan kompetensi pegawai dengan kebutuhan organisasi. Komponen yang terkait dengan sistem pembinaan karier pegawai meliputi :

1. Misi, Sasaran dan Prosedur Organisasi, yang merupakan indikator umumkinerja, kebutuhan prasarana dan sarana termasuk kebutuhan kualitatif dan kuantitatif sumber daya manusia yang mengawakinya.

2. Peta jabatan, yang merupakan refleksi komposisi jabatan, yang secara vertikal menggambarkan struktur kewenangan tugas dan tanggung jawab jabatan dan secara horizontal menggambarkan pengelompokan jenis dan spesifikasi tugas dalam organisasi.

3. Standar konperensi, yaitu tingkat kebolehan, lingkup tugas dan syarat jabatan yang harus dipenuhi untuk menduduki suatu jabatan agar dapat tercapai sasaran organisasi yang menjadi tugas, hak, kewajiban dan tanggung jawab dari pemangku jabatan. 
4. Alur karier, yaitu pola alternatif lintasan perkembangan dan kemajuan pegawai negeri sepanjang pengabdiannya dalam organisasi. Sesuai dengan filosofi bahwa perkembangan karier. Pegawai harus mendorong peningkatan prestasi pegawai.

Alur karier adalah pola gerakan posisi pegawai baik secara horizontal maupun vertikal selalu mengarah pada tingkat posisi yang lebih tinggi.

1. Standar penilaian kinerja pegawai, yaitu instrumental untuk mengukur tingkat kinerja pegawai di bandingkan dengan standar kompetensi jabatan yang sedang dan akan diduduki pegawai yang bersangkutan

2. Pendidikan dan Pelatihan Pegawai, yaitu supaya untuk menyelaraskan kinerja pegawai dan atau orang dari luar organisasi yang akan menduduki Suatu jabatan dengan standar kompetensi yang ditetapkan. Upaya ini dilakukan melalui jalur pendidikan, pelatihan pra jabatan, dan atau pelatihan di dalam jabatan.

3. Rencana Suksesi (Seccession Plan), yaitu rencana mutasi jabatan yang di susun berdasarkan tingkat potensi pegawai, dikaitkan dengan pola jabatan dan standar kompetensi. Rencana suksesi disusun dengan memperhatikan perkiraan kebutuhan organisasi mendatang dikaitkan dengan perencanaan pegawai dan hasil pengkajian potensi pegawai.

\section{OBJEK PENELITIAN DAN METODOLOGI}

\subsection{Gambaran Umum}

\section{Sejarah Dinas Perhubungan Provinsi Lampung}

Provinsi Lampung sebelum tanggal 18 Maret 1964 adalah merupakan Keresidenan Lampung, yang berdasarkan Peraturan Pemerintah Nomor 3 Tahun 1964, yang kemudian menjadi Undang-Undang Nomor 14 Tahun 1964 Keresidenan Lampung ditingkatkan menjadi Provinsi Lampung dengan Ibukota Tanjungkarang - Teluk betung. Selanjutnya Kota madya TanjungkarangTeluk betung tersebut berdasarkan Peraturan Daerah Nomor 24 Tahun 1983 telah diganti namanya menjadi Kota madya Bandar lampung terhitung sejak tanggal 17 Juni 1983.

Sebagai tindak lanjut telah ditetapkannya UU. No. 32 Tahun 2004 tentang Pemerintahan Daerah dan Peraturan Pemerintahan No. 84 Tahun 2000, Tentang Pedoman Organisasi Perangkat Daerah, maka Pemda Provinsi Lampung telah menetapkan Perda No. 15 Tahun 2000, tentang Organisasi dan Tata Kerja Sekretariat Daerah Provinsi Lampung dan Sekretariat DPRD Provinsi Lampung. Selain itu telah ditetapkannya pula Perda No. 16 Tahun 2000, tentang Pembentukan Lembaga Teknis Daerah Provinsi Lampung yang terdiri atas 8 Badan dan 3 Kantor dan Perda Nomor 17 Tahun 2000, tentang Organisasi dan Tata Kerja Dinas Provinsi Lampung, yang terdiri atas 19. Berdasarkan Perda No. 17/2000 Struktur Organisasi Dinas Perhubungan Provinsi Lampung terdiri dari Kepala Dinas, Wakil Kepala 
Dinas, Bagian Tata Usaha, dan 5 (lima) Sub Dinas (yaitu Sub Dinas Bina Program, Perhubungan Darat, Perhubungan Laut, perhubungan Udara, Pos dan Telekomunikasi) serta Unit Pelaksana Teknis Dinas (UPTD) dan Kelompok Jabatan Fungsional.

\section{Visi \& Misi}

\section{Visi}

Terwujudnya jasa perhubungan yang berdaya saing, mampu melayani kebutuhan masyarakat dan mendukung perekonomian daerah.

\section{Misi}

1. Meningkatkan pelayanan jasa perhubungan.

2. Meningkatkan kualitas dan kuantitas sarana dan prasarana perhubungan.

3. Memperluas jaringan pelayanan jasa perhubungan.

4. Meningkatkan kualitas SDM Perhubungan.

\section{Tugas Pokok \& Fungsi}

\section{Tugas pokok}

Menyelenggarakan sebagian kewenangan provinsi (desentralisasi) di bidang perhubungan yang menjadi kewenangannya tugas dekonsentrasi dan tugas perbantuan yang diberikan pemerintah kepada gubernur, serta tugas lain Sesuai dengan kebijaksanaan yang ditetapkan oleh gubernur peraturan perundang-undangan yang berlaku.

\section{Fungsi}

Dalam penyelenggaraan tugasnya Dinas perhubungan mempunyai fungsi sebagai berikut:
1. Perumusan kebijaksanaan, pengaturan, perencanaan dan penetapan standar/ pedoman skala provinsi;

2. Penyusunan, kebijakan, dan penetapan rencana umum jaringan transportasi jalan nasional dan provinsi;

3. Penetapan lokasi, pengesahan rancang bangun dan _persetujuan pengoperasian terminal penumpang Type B;

4. Penyusunan jaringan trayek dan penetapan kebutuhan kendaraan untuk angkutan yang wilayah pelayanannya melebihi wilayah Kabupaten/Kota dalam suatu Provinsi;

5. Penetapan tarif penumpang bus antar Kabupaten/Kota dan tarif angkutan penyeberangan kelas ekonomi pada lintas penyeberangan yang terletak pada jaringan Provinsi;

6. Penentuan lokasi, pengadaan, pemasangan dan penghapusan rambu lalu lintas, marka jalan dan alat pemberi isyarat lalu lintas, alat pengendali dan pengamanan pemakai jalan serta fasilitas pendukung di jalan Provinsi;

7. Pengoperasian dan pemeliharaan unit penimbangan kendaraan bermotor;

8. Penyelenggaraan manajemen dan rekayasa lalu lintas di jalan Provinsi;

9. Penyusunan dan Penetapan rencana umum lintas penyeberangan Kabupaten/Kota;

10. Penyelenggaraan, pengelolaan pelabuhan dan Bandar Udara serta jembatan timbang;

11. Pelayanan dan pengendalian kelebihan muatan dan tertib pemanfaatan jalan provinsi; 
12. Penetapan sasaran dan arah kebijakan pengembangan sistem perkeretaapian;

13. Pelaksanaan pengawasan keselamatan kapal;

14. Pengelolaan pelabuhan regional lama dan pelabuhan baru yang dikelola provinsi;

15. Pelaksanaan koordinasi dan pemantauan terhadap kegiatan angkutan udara dan jaringan rute penerbangan;

16. Pelaksanaan keselamatan penerbangan;

17. Pelayanan administratif;

18. Pelaksanaan tugas lain yang diberikan oleh Gubernur sesuai dengan tugasdan fungsinya.

\section{Kewenangan}

Berdasarkan PP No. 38 Tahun 2007 tentang Pembagian Urusan Pemerintahan Antara Pemerintah, Pemerintah Daerah Provinsi, Pembagian Urusan Pemerintah antara Pemerintah, pemerintah Daerah Provinsi, Dan Pemerintahan Daerah Kabupaten/Kota, Bidang Perhubungan adalah sebagai berikut:

1. Penyusunan dan penetapan rencana umum jaringan transportasi jalan provinsi.

2. Pengawasan dan pengendalian operasional terhadap pengguna jalan selain untuk kepentingan lalu lintas di jalan nasional dan jalan provinsi.

3. Penetapan lokasi terminal penumpang Tipe B.

4. Pengendali dan pengaman pemakai jalan serta fasilitas pendukung di jalan
5. Pengoperasian dan pemeliharaan unit penimbangan kendaraan bermotor.

6. Penyelenggaraan manajemen dan rekayasa lalu lintas di jalan provinsi.

7. Penyelenggaraan analisis dampak lalu lintas (andalalin) di jalan provinsi.

8. Penyelenggaraan pencegahan dan penanggulangan kecelakaan lalu lintas di jalan provinsi.

9. Penelitian dan pelaporan kecelakaan lalu lintas di jalan yang mengakibatkan korban meninggal dunia dan/atau yang menjadi isu provinsi

10. Pemeriksaan kendaraan di jalan sesuai kewenangannya.

11. Pemberian izin operasi angkutan sewa berdasarkan kuota yang ditetapkan pemerintah.

12. Pengoperasian alat penimbang kendaraan bermotor di jalan.

13. Perizinan penggunaan jalan selain untuk kepentingan lalu lintas di jalan provinsi.

14. Pelaksanaan penyidikan pelanggaran :

a. Perda provinsi bidang LLAJ.

b. Pemenuhan persyaratan teknis dan layak jalan

c. Pelanggaran ketentuan pengujian berkala.

d. Perizinan angkutan umum.

15. Pengumpulan, pengolahan data dan analisis kecelakaan lalu lintas di wilayah provinsi.

16. Penyusunan dan penetapan rencana umum jaringan sungai dan danau antar kabupaten/kota dalam provinsi.

17. Penyusunan dan penetapan rencana umum lintas penyeberangan antar kabupaten/kota dalam provinsi 
yang terletak pada jaringan jalan provinsi.

18. Penetapan lintas penyeberangan antar kabupaten/kota dalam provinsi yang terletak pada jaringan jalan provinsi.

19. Pengadaan kapal SDP

20. Pengawasan terhadap pemberian surat ukur, surat tanda pendaftaran dan tanda pendaftaran, sertifikat kelayakan kapal, sertifikat pengawakan kapal, dan surat tanda kebangsaan kapal sungai dan danau $<7$ GT.

21. Rekomendasi lokasi pelabuhan penyeberangan.

22. Pembangunan pelabuhan SDP

23. Pemberian rekomendasi rencana induk, pelabuhan penyeberangan DLKx/DLKp yang terletak pada jaringan jalan nasional dan antar Negara serta jaringan jalur kereta api.

24. Penetapan rencana induk, DLKr/DLKp pelabuhan penyeberangan yang terletak pada jaringan jalan provinsi.

25. Penetapan kelas alur pelayaran sungai.

26. Pengadaan pemasangan dan pemeliharaan rambu penyeberangan.

27. Pemetaan alur sungai lintas kabupaten/kota dalam provinsi untuk kebutuhan transportasi.

28. Pembangunan, pemeliharaan, pengerukan alur pelayaran sungai dan danau.

29. Izin pembangunan prasarana yang melintasi alur sungai dan danau.

30. Penetapan tarif angkutan penyeberangan kelas ekonomi pada lintas penyeberangan yang terletak pada jaringan jalan provinsi.
31. Penetapan tarif angkutan sungai dan danau kelas ekonomi antar kabupaten/kota dalam provinsi.

32. Pengawasan pelaksanaan tarif angkutan SDP antar kabupaten/kota dalam provinsi yang terletak pada jaringan jalan provinsi.

33. Pemberian persetujuan pengoperasian kapal untuk lintas penyeberangan antar kabupaten/ kota dalam provinsi pada jaringan jalan provinsi.

34. Pengawasan pengoperasian penyelenggaraan angkutan sungai dan danau.

35. Pengawasan penyelenggaraan penyeberangan antar kabupaten/kota dalam provinsi pada jaringan jalan provinsi.

36. Pengawasan angkutan barang berbahaya dan khusus melalui angkutan SDP.

Berdasarkan Keputusan Menteri Perhubungan No. Km 46 dan Km 49 tahun 2002 serta $\mathrm{Km} \mathrm{38}$, Km 55 dan Km 77 tahun 2003, kewenangan dekonsentrasi dibidang pos dan telekomunikasi adalah:

1. Penerbitan Izin Amatir Radio ( IAR ) dan Izin Penguasaan Perangkat Radio Amatir (IPPRA)

2. Penerbitan Izin Komunikasi Radio Antar Penduduk Indonesia ( IKRAP ) dan Izin Penguasaan Perangkat ( IPPKRAP)

3. Penerbitan Instalasi Kabel Rumah/Gedung (IKR/G)

4. Penerbitan Izin Usaha Jasa Titipan (Cabang dan Agen)

5. Penerbitan Izin Stasiun Radio Lokal

6. Rekomendasi Jasa Titipan untuk Kantor Pusat 
7. Pengawasan dan penerbitan terhadap pengguna frekuensi radi, jasa, titipan, wartel, dan Uso.

8. Penertiban Izin Siaran TV Lokal.

9. Pembinaan/pengawasan penyalur/penjual perangkat telekomunikasi ( Radi Equipment Dealer).

\subsection{Metodologi Penelitian}

\section{Tipe dan metode penelitian}

a. Tipe Penelitian ini adalah penelitian lapangan atau Field Research, yaitu penelitian yang membahas permasalahanpermasalahan yang ada di lapangan atau lokasi penelitian.

b. Metode Penelitian Metode penelitian yang dipergunakan dalam pembahasan penelitian ini adalah Metode Deskriptif, di karena kan data yang dikumpulkan merupakan data kuantitatif atau data yang berupa angka-angka yang didapatkan dari hasil penyebaran angket ( kuesioner.) kepada sampel penelitian.

Sumber data dalam pelaksanaan penelitian ini di dapat dari:

a. Data Primer, yaitu data yang didapatkan langsung dari staf Protokol yang dijadikan sampel penelitian yaitu data-data yang berhubungan dengan peranan Bidang Personalia Terhadap Pembinaan Pegawai di Dinas Perhubungan Kota Bandar Lampung.

b. Data sekunder, yaitu data yang diperoleh dari staf personalia Dinas Perhubungan Kota Bandar Lampung sebagai data penunjang/pelengkap pembahasan penelitian, seperti tentang sejarah berdirinya Kantor Perhubungan Provinsi Lampung dan sebagainya yang berhubungan dengan Peranan Bidang Personalia Terhadap Pembinaan Pegawai di Dinas Perhubungan Kota Bandar Lampung.

\section{Teknik Pengumpulan Data}

Untuk mengumpulkan data, penulis menggunakan teknik sebagai berikut:

a. Penelitian Kepustakaan; penulis mencari keteranganketerangan yang berlaku secara umum yang dikarang para ahli, terutama yang berkaitan dengan penulisan skripsi yang digunakan sebagai landasan pengolahan data.

b. Wawancara; teknik wawancara ini penulis akan mengadakan interviu langsung dengan responden untuk memperoleh penjelasan dan keteranganketerangan yang berkaitan dengan penelitian. Data yang akan dikumpulkan melalui wawancara ini adalah data tentang Peranan Bidang Personalia Terhadap Pembinaan Pegawai Di Dinas Perhubungan Kota Bandar Lampung

c. Observasi; penulis melakukan pengamatan dan pencatatan secara Sistematis dan berbagai fenomena yang muncul dalam Peranan Bidang Personalia Terhadap Pembinaan Pegawai Di Dinas Kota Bandar Lampung 
d. Dokumentasi; teknik dokumentasi penulis dipergunakan untuk mengumpulkan data yang berasal dari catatan-catatan arsip yang ada pada Dinas Perhubungan Kota Bandar Lampung

e. Angket; teknik angket atau kuesioner akan digunakan dengan menggunakan daftar pertanyaan yang berhubungan dengan Peranan Bidang Personalia Terhadap Pembinaan Pegawai Di Dinas Kota Bandar Lampung. Pada angket tersebut di persiapkan 20 pertanyaan, masing-masing variabel terdiri dari 10 pertanyaan, 3 alternatif jawaban, setiap pertanyaan disajikan dalam bentuk multipel choice item dengan kriteria sebagai berikut:

1) Untuk jawaban (A) diberi skor tiga (baik)

2) Untuk jawaban (B) diberi skor dua (kurang baik)

3) Untuk jawaban (C) diberi skor satu (tidak baik)

\section{Teknik Pengolahan Data}

Data-data yang telah berhasil dikumpulkan dari hasil penelitian, yaitu dari hasil penyebaran angket, wawancara dan observasi.

\section{PEMBAHASAN}

\subsection{Analisa Kualitatif}

Analisa kualitatif adalah suatu analisa dengan menggunakan suatu uraianuraian yang berbentuk kalimat-kalimat dengan cara membandingkan teori-teori yang ada dengan kenyataan yang ada di lapangan (Hadi, 1999).

\section{Peranan Bidang Personalia (variabel $x)$}

Tabel 1. Tanggapan responden tentang apakah bidang personalia mempunyai perencanaan pembinaan yang baik untuk karir pegawai

\begin{tabular}{|l|c|c|}
\hline \multicolumn{1}{|c|}{ Kategori } & f & \% \\
\hline Baik & 25 & $100 \%$ \\
\hline Cukup baik & - & - \\
\hline Kurang Baik & - & - \\
\hline Jumlah & $\mathbf{2 5}$ & $\mathbf{1 0 0 \%}$ \\
\hline
\end{tabular}

Sumber : Hasil angket diolah September 2012

Dari tabel 1 menunjukkan bahwa tanggapan responden mengenai apakah bidang personalia mempunyai perencanaan pembinaan yang baik untuk karir pegawainya, didapat hasil angket seperti berikut: bahwa 25 responden atau $100 \%$ responden menyatakan bahwa bidang personalia mempunyai perencanaan pembinaan yang baik untuk karir pegawainya.

Tabel 2. Tanggapan responden tentang apakah bidang personalia mempunyai perencanaan pembinaan yang baik untuk keahlian pegawai

\begin{tabular}{|l|c|c|}
\hline \multicolumn{1}{|c|}{ Kategori } & f & \% \\
\hline Baik & 23 & $92 \%$ \\
\hline Cukup baik & 2 & $8 \%$ \\
\hline Kurang Baik & - & - \\
\hline \multicolumn{1}{|c|}{ Jumlah } & $\mathbf{2 5}$ & $\mathbf{1 0 0 \%}$ \\
\hline
\end{tabular}

Sumber : Hasil angket diolah September 2012 
Dari tabel 2 menunjukkan bahwa tanggapan responden mengenai apakah bidang personalia mempunyai perencanaan pembinaan yang baik untuk keahlian pegawainya, didapat hasil angket seperti berikut: bahwa 23 responden atau 92\% responden menyatakan bahwa bidang personalia mempunyai perencanaan pembinaan yang baik untuk keahlian pegawainya, sedangkan 2 responden atau $8 \%$ responden menyatakan bidang personalia mempunyai perencanaan pembinaan yang cukup baik untuk keahlian pegawainya.

Tabel 3. Tanggapan responden tentang apakah tugas yang dilakukan bidang personalia sesuai dengan aturan yang berlaku

\begin{tabular}{|l|c|c|}
\hline \multicolumn{1}{|c|}{ Kategori } & f & \% \\
\hline Sesuai & 22 & $88 \%$ \\
\hline Cukup sesuai & 3 & $12 \%$ \\
\hline Kurang sesuai & - & - \\
\hline Jumlah & $\mathbf{2 5}$ & $\mathbf{1 0 0 \%}$ \\
\hline
\end{tabular}

Sumber : Hasil angket diolah September 2012

Dari tabel 3 Menunjukkan bahwa tanggapan responden mengenai apakah tugas yang dilakukan bidang personalia sesuai dengan aturan yang berlaku, didapat hasil angket seperti berikut: bahwa 22 responden atau $66 \%$ responden menyatakan bahwa tugas yang dilakukan bidang personalia sesuai dengan aturan yang beriaku, sedangkan 3 responden atau $12 \%$ responden menyatakan tugas yang dilakukan bidang personalia cukup sesuai dengan aturan yang berlaku.

Tabel 4. Tanggapan responden tentang apakah mengerti akan jenjang karir kepegawaian dilingkungan Dinas Perhubungan Kota Bandar Lampung

\begin{tabular}{|l|c|c|}
\hline \multicolumn{1}{|c|}{ Kategori } & f & \% \\
\hline Mengerti & 23 & $92 \%$ \\
\hline Cukup mengerti & 2 & $8 \%$ \\
\hline Kurang mengerti & - & - \\
\hline Jumlah & $\mathbf{2 5}$ & $\mathbf{1 0 0 \%}$ \\
\hline
\end{tabular}

Sumber : Hasil angket diolah September 2012

Dari tabel 4 menunjukkan bahwa tanggapan responden mengenai apakah mengerti akan jenjang karir kepegawaian di lingkungan Dinas Perhubungan Kota Bandar Lampung, didapat hasil angket seperti berikut: bahwa 23 responden atau 92\% responden menyatakan bahwa mengerti akan jenjang karir kepegawaian di lingkungan Dinas Perhubungan Kota Bandar Lampung, sedangkan 2 responden atau $8 \%$ responden menyatakan cukup mengerti akan jenjang karir kepegawaian di lingkungan Dinas Perhubungan Kota Bandar Lampung.

Tabel 5. Tanggapan responden tentang apakah mengerti tugas dan fungsi masingmasing bidang yang ada di Dinas Perhubungan Kota BandarLampung

\begin{tabular}{|l|c|c|}
\hline \multicolumn{1}{|c|}{ Kategori } & f & \% \\
\hline Mengerti & 17 & $68 \%$ \\
\hline Cukup mengerti & 8 & $32 \%$ \\
\hline Kurang mengerti & - & - \\
\hline Jumlah & $\mathbf{2 5}$ & $\mathbf{1 0 0 \%}$ \\
\hline
\end{tabular}

Sumber : Hasil angket diolah September 2012

Dari tabel 5 Menunjukkan bahwa tanggapan responden mengenai apakah mengerti tugas dan fungsi masing-masing bidang yang ada di Dinas Perhubungan Kota Bandar Lampung, didapat hasil 
angket seperti berikut: bahwa 17 responden atau $68 \%$ responden menyatakan bahwa ia mengerti tugas dan fungsi masing-masing bidang yang ada di Dinas Perhubungan Kota Bandar Lampung, sedangkan 8 responden atau $32 \%$ responden menyatakan cukup mengerti tugas dan fungsi masingmasing bidang yang ada di Dinas Perhubungan Kota Bandar Lampung.

Tabel 6. Tanggapan responden tentang apakah mengerti tugas saudara

\begin{tabular}{|l|c|c|}
\hline \multicolumn{1}{|c|}{ Kategori } & f & \% \\
\hline Mengerti & 24 & $96 \%$ \\
\hline Cukup mengerti & 1 & $4 \%$ \\
\hline Kurang mengerti & - & - \\
\hline Jumlah & $\mathbf{2 5}$ & $\mathbf{1 0 0 \%}$ \\
\hline
\end{tabular}

Sumber : Hasil angket diolah September 2012

Dari tabel 6 Menunjukkan bahwa tanggapan responden mengenai apakah mengerti tugasnya di Dinas PerhubunganKota Bandar Lampung, didapat hasil angket seperti berikut: bahwa 24 responden atau $96 \%$ responden menyatakan bahwa ia mengerti tugasnya $\mathrm{i}$ Dinas PerhubunganKota Bandar Lampung, sedangkan 1 responden atau $4 \%$ responden menyatakan cukup mengerti tugasnya di Dinas PerhubunganKota Bandar Lampung.

Tabel 7. Tanggapan responden tentang apakah selalu mengikuti arahan pimpinan

\begin{tabular}{|l|c|c|}
\hline \multicolumn{1}{|c|}{ Kategori } & f & \% \\
\hline Mengikuti & 20 & $80 \%$ \\
\hline Cukup mengikuti & 2 & $20 \%$ \\
\hline Kurang mengikuti & - & - \\
\hline
\end{tabular}

\begin{tabular}{|c|c|c|}
\hline Jumlah & 25 & $100 \%$ \\
\hline
\end{tabular}

Sumber : Hasil angket diolah September 2012

Dari tabel 7 menunjukkan bahwa tanggapan responden mengenai apakah selalu mengikuti arahan pimpinan, didapat hasil angket seperti berikut: bahwa 20 responden atau $80 \%$ responden menyatakan bahwa ia mengikuti arahan pimpinan, sedangkan 5 responden atau $20 \%$ responden menyatakan cukup mengikuti arahan pimpinan di Dinas Perhubungan Kota Bandar Lampung.

Tabel 8. Tanggapan responden tentang apakah selalu dating tepat waktu

\begin{tabular}{|c|c|c|}
\hline Kategori & f & \% \\
\hline Selalu tepat waktu & 15 & $60 \%$ \\
\hline Kadang - kadang & 10 & $40 \%$ \\
\hline Tidak tepat waktu & - & - \\
\hline Jumlah & $\mathbf{2 5}$ & $\mathbf{1 0 0 \%}$ \\
\hline
\end{tabular}

Sumber : Hasil angket diolah September 2012

Dari tabel 8 menunjukkan bahwa tanggapan responden mengenai apakah selalu datang tepat waktu, didapat hasil angket seperti berikut: bahwa 15 responden atau $60 \%$ responden selalu datang tepat waktu, sedangkan 10 responden atau 40\% responden menyatakan kadang-kadang datang tepat waktu.

Tabel 9. Tanggapan responden tentang apakah selalu mengikuti arahan pimpinan

\begin{tabular}{|l|c|c|}
\hline \multicolumn{1}{|c|}{ Kategori } & f & \% \\
\hline Senang & 24 & $96 \%$ \\
\hline Cukup senang & 1 & $4 \%$ \\
\hline
\end{tabular}




\begin{tabular}{|c|c|c|}
\hline Kuraang senang & - & - \\
\hline Jumlah & $\mathbf{2 5}$ & $\mathbf{1 0 0 \%}$ \\
\hline
\end{tabular}

Sumber : Hasil angket diolah September 2012

Dari tabel 9 menunjukkan bahwa tanggapan responden mengenai apakah senang dalam melakukan pelayanan terhadap masyarakat, didapat hasil angket seperti berikut: bahwa 24 responden atau 96\% responden apakah senang dalam melakukan pelayanan terhadap masyarakat, sedangkan 1 responden atau $4 \%$ responden menyatakan cukup apakah senang dalam melakukan pelayanan terhadap masyarakat.

Tabel 10. Tanggapan responden tentang apakah selalu bekerja sesuai jam kerja yang ada

\begin{tabular}{|l|c|c|}
\hline \multicolumn{1}{|c|}{ Kategori } & f & \% \\
\hline Sesuai & 17 & $68 \%$ \\
\hline Cukup sesuai & 8 & $32 \%$ \\
\hline Kurang sesuai & - & - \\
\hline \multicolumn{1}{|c|}{ Jumlah } & $\mathbf{2 5}$ & $\mathbf{1 0 0 \%}$ \\
\hline
\end{tabular}

Sumber : Hasil angket diolah September 2012

Dari tabel 10 menunjukkan bahwa tanggapan responden mengenai apakah walau bekerja sesuai dengan jam kerja yang ada, didapat hasil angket seperti cut: bahwa 17 responden atau $68 \%$ responden selalu bekerja sesuai dengan jam kerja yang ada, sedangkan 8 responden atau $16 \%$ responden menyatakan selalu bekerja cukup sesuai dengan jam kerja yang ada.

Tabel 11. Tanggapan responden tentang latar belakang pendidikan anda sesuai dengan bidang kerjaan responden

\begin{tabular}{|l|c|c|}
\hline \multicolumn{1}{|c|}{ Kategori } & f & \% \\
\hline Sesuai & 13 & $52 \%$ \\
\hline Cukup sesuai & 12 & $48 \%$ \\
\hline Kurang sesuai & - & - \\
\hline Jumlah & $\mathbf{2 5}$ & $\mathbf{1 0 0 \%}$ \\
\hline
\end{tabular}

Sumber :Hasil angket diolah September 2012

Dari tabel 11 menunjukkan bahwa tanggapan responden mengenai latar belakang pendidikan anda sesuai dengan bidang kerja responden, didapat hasil angket seperti berikut: bahwa 13 responden atau $52 \%$ responden menyatakan latar belakang pendidikan anda sesuai dengan bidang kerja responden, sedangkan 12 responden atau $48 \%$ responden menyatakan latar belakang pendidikan cukup sesuai dengan bidang kerja responden.

Tabel 12. Tanggapan responden tentang apakah sering mengikuti pelatihan yang dilaksanakan Dinas Perhubungan Kota Bandar Lampung

\begin{tabular}{|l|c|c|}
\hline \multicolumn{1}{|c|}{ Kategori } & f & \% \\
\hline Cepat & 13 & $52 \%$ \\
\hline Cukup cepat & 12 & $48 \%$ \\
\hline Kurang cepat & - & - \\
\hline Jumlah & $\mathbf{2 5}$ & $\mathbf{1 0 0 \%}$ \\
\hline
\end{tabular}

Sumber :Hasil angket diolah September 2012

Dari tabel 12 menunjukkan bahwa tanggapan responden mengenai apakah sering mengikuti pelatihan yang diadakan Dinas Perhubungan Kota Bandar Lampung, didapat hasil angket seperti berikut: bahwa 13 responden atau 52\% responden 
menyatakan mereka sering mengikuti pelatihan yang diadakan Dinas Perhubungan Kota Bandar Lampung, sedangkan 12 responden atau 48\% responden menyatakan mereka cukup sering mengikuti pelatihan yang diadakan Dinas Perhubungan Kota Bandar Lampung.

Tabel 13. Tanggapan responden tentangsejauh manatingkat kesalahan dalam memberikan pelayanan

\begin{tabular}{|l|c|c|}
\hline \multicolumn{1}{|c|}{ Kategori } & f & \% \\
\hline Tidak terjadi kesalahan & 11 & $44 \%$ \\
\hline Kadang- kadang & 14 & $56 \%$ \\
\hline Terjadi kesalahan & - & - \\
\hline \multicolumn{1}{|c|}{ Jumlah } & $\mathbf{2 5}$ & $\mathbf{1 0 0 \%}$ \\
\hline
\end{tabular}

Sumber :Hasil angket diolah September 2012

Dari tabel 13 menunjukkan bahwa tanggapan responden tentang, Sejauh mana tingkat kesalahan dalam memberikan pelayanan, didapat hasil angket seperti perikut: bahwa 11 responden atau $44 \%$ responden menyatakan tidak terjadi kesalahan dalam memberikan pelayanan kesehatan terhadap masyarakat, sedangkan jam kerja sudah habis, sedangkan 14 responden atau $56 \%$ responden menyatakan kadang-kadang terjadi kesalahan dalam memberikan pelayanan kesehatan kepada masyarakat.

Tabel 14. Tanggapan responden tentang kesesuaian pelayanan dengan peraturan prosedur pelayanan

\begin{tabular}{|l|c|c|}
\hline \multicolumn{1}{|c|}{ Kategori } & f & \% \\
\hline Sesuai & 10 & $40 \%$ \\
\hline Kadang-kadang & 15 & $60 \%$ \\
\hline
\end{tabular}

\begin{tabular}{|c|c|c|}
\hline Tidak sesuai & - & - \\
\hline Jumlah & $\mathbf{2 5}$ & $\mathbf{1 0 0 \%}$ \\
\hline
\end{tabular}

Sumber :Hasil angket diolah September 2012

Dari tabel 14 menunjukkan bahwa tanggapan responden mengenai bagaimana kesesuaian pelayanan dengan peraturan prosedur pelayanan, didapat hasil angket seperti berikut: bahwa 10 responden atau $40 \%$ responden menyatakan pelayanan masyarakat di Dinas Perhubungan Kota Bandar Lampung sesuai dengan peraturan atau prosedur yang berlaku, sedangkan 15 responden atau $60 \%$ responden menyatakan pelayanan masyarakat di Dinas Perhubungan Kota Bandar Lampung kadang-kadang sesuai dengan peraturan atau prosedur yang berlaku.

Tabel 15. Tanggapan responden tentang ada kendala apabila pelayanan diterapkan sesuai dengan prosedur dan peraturan yang ada

\begin{tabular}{|l|c|c|}
\hline \multicolumn{1}{|c|}{ Kategori } & f & \% \\
\hline Tidak terjadi kendala & 12 & $48 \%$ \\
\hline Kadang-kadang & 13 & $52 \%$ \\
\hline Terjadi kendala & - & - \\
\hline \multicolumn{1}{|c|}{ Jumlah } & $\mathbf{2 5}$ & $\mathbf{1 0 0 \%}$ \\
\hline
\end{tabular}

Sumber :Hasil angket diolah September 2012

Dari tabel 15 menunjukkan bahwa tanggapan responden mengenai apakah ada kendala apabila pelayanan diterapkan sesuai dengan prosedur dan peraturan yang ada, didapat hasil angket seperti berikut: bahwa 12 responden atau $48 \%$ responden menyatakan ada kendala apabila pelayanan diterapkan sesuai dengan prosedur dan 
peraturan yang ada, sedangkan 13 responden atau $52 \%$ responden menyatakan kadang-kadang ada kendala apabila pelayanan diterapkan sesuai dengan prosedur dan peraturan yang ada.

Tabel 16. Tanggapan responden tentang kesalahan pelayanan apakah petugas bertanggung jawab memperbaikinya

\begin{tabular}{|l|c|c|}
\hline \multicolumn{1}{|c|}{ Kategori } & f & \% \\
\hline Bertanggung jawab & 12 & $48 \%$ \\
\hline $\begin{array}{l}\text { Kadang- kadang bertanggung } \\
\text { jawab }\end{array}$ & 13 & $52 \%$ \\
\hline Tidak bertanggung jawab & - & - \\
\hline \multicolumn{1}{|c|}{ Jumlah } & $\mathbf{2 5}$ & $\mathbf{1 0 0 \%}$ \\
\hline
\end{tabular}

Sumber :Hasil angket diolah September 2012

Dari tabel 16 menunjukkan bahwa tanggapan responden mengenai apabila terjadi kesalahan pelayanan apakah petugas bertanggungjawab memperbaikinya, didapat hasil angket seperti berikut: bahwa 12 responden atau $48 \%$ responden menyatakan bahwa apabila terjadi kesalahan pelayanan petugas bertanggungjawab memperbaikinya, sedangkan 13 responden atau 52\% responden menyatakan apabila terjadi kesalahan pelayanan petugas kadangkadang bertanggungjawab memperbaikinya.

Tabel 17. Tanggapan responden tentangpernah terjadi kesalahan prosedur pelayanan terhadap masyarakat

\begin{tabular}{|l|c|c|}
\hline \multicolumn{1}{|c|}{ Kategori } & f & \% \\
\hline Tidak pernah & 15 & $60 \%$ \\
\hline Kadang-kadang & 10 & $40 \%$ \\
\hline
\end{tabular}

\begin{tabular}{|c|c|c|}
\hline Ada/ pernah & - & - \\
\hline Jumlah & $\mathbf{2 5}$ & $\mathbf{1 0 0 \%}$ \\
\hline
\end{tabular}

Sumber :Hasil angket diolah September 2012

Dari tabel 17 menunjukkan bahwa tanggapan responden mengenai apakah pernah terjadi kesalahan prosedur pelayanan dari Dinas Perhubungan Kota Bandar Lampung terhadap masyarakat, didapat hasil angket seperti berikut: bahwa 15 responden atau $60 \%$ responden Menyatakan bahwa pernah terjadi kesalahan prosedur pelayanan terhadap masyarakat, sedangkan 10 responden atau $40 \%$ responden menyatakan kadang-kadang pernah terjadi kesalahan prosedur.

Tabel 18. Tanggapan responden tentang bagaimana informasi tertulis tentang pelayanan kepada masyarakat

\begin{tabular}{|l|c|c|}
\hline \multicolumn{1}{|c|}{ Kategori } & f & \% \\
\hline Akurat dan jelas & 11 & $44 \%$ \\
\hline Cukup akurat dan jelas & 14 & $56 \%$ \\
\hline Tidak akurat dan jelas & - & - \\
\hline Jumlah & $\mathbf{2 5}$ & $\mathbf{1 0 0 \%}$ \\
\hline
\end{tabular}

Sumber :Hasil angket diolah September 2012

Dari tabel 18 menununjukkan bahwa tanggapan responden mengenai bagaimana informasi tertulis tentang pelayanan kepada masyarakat, didapat hasil angket seperti berikut: bahwa 11 responden atau $44 \%$ responden menyatakan bahwa informasi tertulis tentang pelayanan akurat dan jelas disampaikan kepada masyarakat, sedangkan 14 responden atau 56\% responden menyatakan informasi tertulis tentang 
pelayanan cukup akurat dan jelas disampaikan kepada masyarakat.

Tabel 19. Tanggapan responden tentang bagaimana penyelesaian kebutuhan pelayanan dari Dinas Perhubungan Kota Bandar Lampung

\begin{tabular}{|l|c|c|}
\hline \multicolumn{1}{|c|}{ Kategori } & f & \% \\
\hline Selalu & 10 & $40 \%$ \\
\hline Kadang-kadang & 15 & $60 \%$ \\
\hline Tidak tepat waktu & - & - \\
\hline \multicolumn{1}{|c|}{ Jumlah } & $\mathbf{2 5}$ & $\mathbf{1 0 0 \%}$ \\
\hline
\end{tabular}

Sumber :Hasil angket diolah September 2012

Dari tabel 19 menunjukkan bahwa tanggapan responden mengenai bagaimana penyelesaian kebutuhan pelayanan dari Dinas Perhubungan Kota Bandar Lampung, didapat hasil angket seperti berikut: bahwa 15 responden atau $60 \%$ responden menyatakan bahwa penyelesaian kebutuhan pelayanan selalu dilaksanakan oleh Pegawai Dinas Perhubungan Kota Bandar Lampung, sedangkan 10 responden atau $40 \%$ responden menyatakan penyelesaian kebutuhan pelayanan kadang-kadang dilaksanakan oleh Pegawai Dinas Perhubungan Kota Bandar Lampung.

Tabel20. Tanggapan responden tentang kotak kritik dan saran dari masyarakat di kantor Dinas Perhubungan Kota Bandar Lampung

\begin{tabular}{|l|c|c|}
\hline \multicolumn{1}{|c|}{ Kategori } & f & \% \\
\hline Ada & 12 & $48 \%$ \\
\hline Tidak tau & 13 & $52 \%$ \\
\hline
\end{tabular}

\begin{tabular}{|c|c|c|}
\hline Tidak ada & - & - \\
\hline Jumlah & $\mathbf{2 5}$ & $\mathbf{1 0 0 \%}$ \\
\hline
\end{tabular}

Sumber :Hasil angket diolah September 2012

Dari tabel 20 menunjukkan bahwa tanggapan responden mengenai adakah yotak kritik dan saran dari masyarakat, didapat hasil angket seperti berikut: bahwa 12 responden atau $48 \%$ responden menyatakan bahwa mereka ada kotak kritik dan saran dari masyarakat di Dinas perhubungan Kota Bandar lampung, sedangkan 13 sesponden atau 52\% responden menyatakan bahwa tidak tau kotak kritik dan saran dari masyarakat di Dinas perhubungan Kota Bandar lampung.

\subsection{Analisa Kuantitatif}

Berdasarkan metode pengumpulan data yang dilakukan melalui daftar pertanyaan maka diharapkan dapat diketahui tingkat hubungan antara Peranan Bidang Personalia (variable $\mathrm{x}$ ) terhadap Pembinaan Pegawai Di Dinas Perhubungan Kota Bandar Lampung (variabel y) dengan menggunakan rumus Korelasi Product Moment sebagai berikut:

$$
r_{x y}=\frac{n\left(\Sigma_{x y}\right)-\left(\Sigma_{y} x\right):\left(\Sigma_{y}\right)}{\sqrt{\left(m \Sigma x^{2}-(\Sigma x)^{2}\right\}\left\{n \Sigma y^{2}-(\Sigma y)^{2}\right\}}}
$$

Keterangan:

$$
\begin{aligned}
& \mathrm{r}_{\mathrm{xy}} \quad=\text { Kooefisien korelasi } \\
& \text { antara } \mathrm{x} \text { dan } \mathrm{y} \\
& \mathrm{x} \quad=\text { Nilai skor bidang } \\
& \text { personalia } \\
& \mathrm{y} \quad=\text { Nilai skor pembina pegawai } \\
& \mathrm{n} \quad=\text { Besarnya sampel yang diambil }
\end{aligned}
$$


Berikut ini adalah tabel hasil perhitungan yang diperoleh dari jawaban responden melalui angket yang disebarkan, diketahui:

$$
\begin{aligned}
& \mathrm{n}=25 \\
& \sum x=710 \\
& \sum \mathrm{y}=619 \\
& \sum \mathrm{x}^{2}=\begin{array}{c}
2020 \\
0
\end{array} \\
& \sum y^{2}=\begin{array}{c}
1543 \\
5
\end{array} \\
& \sum x y=6
\end{aligned}
$$

Dan langkah selanjutnya adalah memasukan nilai-nilai diatas kedalam rumus produk momen, jadi bila dimasukkan kedalam rumus akan didapat perhitungan sebagai berikut

$$
\begin{aligned}
& r_{x y}=\frac{25(17596)-(710) .(619)}{\left.\sqrt{\{25.20200}-(710)^{2}\right\}\left\{25.15435-(619)^{2}\right\}} \\
& r_{x y}=\frac{439900-439090}{\sqrt{\{505000}-(504100\}\{385875-383161\}} \\
& r_{x y}=\frac{810}{\sqrt{2442600}} \\
& r_{x y}=\frac{810}{1562,88195} \\
& r_{x y}=0,518
\end{aligned}
$$

Berdasarkan hasil perhitungan, maka di dapat untuk $r$ hitung adalah 0,518. Apabila dikonsultasikan dengan rtabel untuk taraf signifikan $5 \%$ adalah 0,396 . Ternyata $\mathrm{r}$ hitung lebih besar dari pada rtabel atau:

r hitung $(0,518)>r$ tabel $(0,396)$ pada taraf signifikan $5 \%$
Dengan demikian Bidang Personalia mempunyai peranan yang positif terhadap Pembinaan Pegawai Di Dinas Perhubungan Kota Bandar Lampung.

\section{KESIMPULAN DAN SARAN}

\subsection{Kesimpulan}

Setelah mengadakan analisa pada bab terdahulu dan dari hasil penelitian yang telah penulis laksanakan, maka penulis mengambil suatu kesimpulan sebagai berikut:

1. Bidang personalia berperan dalam pembinaan pegawai di Dinas Perhubungan Kota Bandar Lampung, hal ini dikarenakan perencanaan dan pembinaan karir serta keahlian pegawai yang baik.

2. Berdasarkan hasil perhitungan, maka di dapat untuk rhitung adalah 0,518. Apabila dikonsultasikan dengan rtabel untuk taraf signifikan $5 \%$ adalah 0,396 . Ternyata $r$ hitung lebih besar dari pada $r$ tabel atau rhitung $(0,518)>\mathrm{r}$ tabel $(0,396)$ pada taraf signifikan 5\%, dengan demikian Bidang Personalia mempunyai peranan yang positif terhadap Pembinaan Pegawai di Dinas Perhubungan Kota Bandar Lampung.

\subsection{Saran}

1. Dengan menambah keahlian pegawai Dinas Perhubungan Kota Bandar Lampung akan sangat membantu memperlancar pelayanan kepada masyarakat.

2. Peningkatan kualitas pegawai Dinas Perhubungan Kota Bandar Lampung juga akan sangat membantu memperlancar penyelesaian tugas yang dihadapi. 
3. Lebih ditingkatkan lagi penanganan pelayanan kepada masyarakat dari Dinas Perhubungan Kota Bandar Lampung.

\section{DAFTAR PUSTAKA}

AB., Susanto, 1996. Keputusan dan Loyalitas Konsumen. Bisnis Indonesia, Jakarta

Arikunto, Suharsini, 1997. Prosedur Penelitian. Rineka Cipta, Jakarta Arikunto, Suharsini, 2004. Prosedur Penelitian, Edisi Revisi. PT. Bina Aksara, Jakarta

Arikunto, Suharsini, 1987. Methodology Research. UGM, Yogyakarta

Cushway, Barry, 1996. Human Resource Management (Manajemen SDM). Gramedia, Jakarta

Cushway, Barry, 1987. Methodology Research. UGM, Yogyakarta

Djamil, 2003. Pengembangan Pegawai. Ghalia Indonesia, Jakarta

Husnan, 2003. Manajemen Personalia, Ghalia Indonesia, Jakarta

Malayu SP., Hasibuan, 2005. Manajemen: Dasar, Pengertian dan Masalah. Bumi Aksara, Jakarta
Manulang, M., 1989. Pengembangan Pegawai. Ghalia Indonesia, Jakarta

Manulang, M., 2003. Manajemen Personalia. Gajah Mada University Press, Yogyakarta

Meokijat, 1992. Manajemen Kepegawaian. Mandar Maju, Bandung

Nawawi, Hadari, 1991. Metode Penelitian Bidang Sosial. Gajah Mada University Press, Yogyakarta

Patton, 2000. Metodologi Penelitian Kualitatif. Salemba Universitas Indonesia, Jakarta

Poerwadarminta, WJS., 1981. Kamus Besar Bahasa Indonesia

Sarwoto, 1990. Dasar-Dasar Organisasi dan Manajemen. Ghalia Indonesia, Jakarta

Supranto, J., 1991. Metode Penelitian dan Aplikasinya dalam Pemasaran. Universitas Indonesia, Jakarta

Suhardi, 2000. Manajemen Kepegawaian di Indonesia. Gunung Agung, Jakarta

Rahman, 2003. Manajemen Personalia. Ghalia Indonesia, Jakarta 